\title{
Modification of conditions for the selective preparation of 2-amino-3-cyano-4-phenylpyridines
}

\author{
Mónica Álvarez-Pérez* and José Marco-Contelles \\ Laboratorio de Radicales Libres y Química Computacional, IQOG (CSIC), \\ C/ Juan de la Cierva 3, 28006 Madrid, Spain \\ E-mail: maperez@iqfr.csic.es, $\underline{\text { iqoc21@iqog.csic.es }}$
}

\begin{abstract}
We herein describe the modification of the experimental conditions for the synthesis of certain 2amino-4-aryl-3-cyanopyridines from benzaldehyde, malononitrile, ammonium acetate and aminoketones. The outcome of the reaction proved to be highly dependent on the experimental procedure, occasionally giving rise to metaphthalodinitriles. Mechanistical proposals are also reported, in order to explain the observed dependence on the procedure.
\end{abstract}

Keywords: Heterocycles, pyridines, medicinal chemistry, condensation, bicyclic compounds

\section{Introduction}

In the context of a current project developed in our laboratory for the synthesis of biologically active molecules, 2-amino-5,6,7,8-tetrahydro-1,6-naphthyridine-3-carbonitriles I (Figure 1) were selected for study as well as 2-aminopyridine- and 2-chloropyridine-3,5-dicarbonitriles. ${ }^{1}$ Particular interest was focused on the highly functionalized molecules 1-3 (Figure 1).

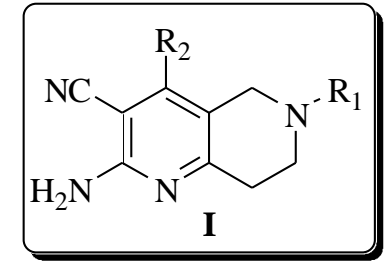

$\mathrm{R}_{1}=\mathrm{H}$, alkyl, Ar, etc. $\mathrm{R}_{2}=\mathrm{H}$, alkyl, Bn, etc.<smiles>[R]N1CCc2nc(N)c(C#N)c(-c3ccccc3)c2C1</smiles>

$1 \mathrm{R}=\mathrm{CH}_{2} \mathrm{Ph}$

$2 \mathrm{R}=\mathrm{CH}_{2} \mathrm{CCH}$

$3 \mathrm{R}=\mathrm{Boc}$

Figure 1. Target 2-amino-5,6,7,8-tetrahydro-1,6-naphthyridine-3-carbonitriles. 
Literature searching shows that very few reports on the preparation of this type of heterocyclic ring system have been published. Among the few examples, 2-amino-6-methyl-4phenyl-5,6,7,8-tetrahydro-1,6-naphthyridine-3-carbonitrile 4 (Figure 2) has recently been included in a patent dealing with compounds altering the lifespan of eukaryotic organisms. ${ }^{2}$ Regarding 2-amino-6-benzyl-5,6,7,8-tetrahydro-1,6-naphthyridine-3-carbonitrile 5 and benzyl 2amino-3-cyano-7,8-dihydro-1,6-naphthyridine-6(5H)-carboxylate $\mathbf{6}$, they have been used as intermediates in the synthesis of partially restricted linear, tricyclic 5-deaza antifolates. ${ }^{3}$ Related tert-butyl 2-amino-4-phenyl-7,8-dihydropyrido[4,3- $d]$ pyrimidine-6(5H)-carboxylate 7 has been described for the preparation of polysubstituted 2-aminopyrimidines. ${ }^{4}$<smiles>CN1CCc2nc(N)c(C#N)c(-c3ccccc3)c2C1</smiles><smiles>N#Cc1cc2c(nc1N)CCN(C(=O)OCc1ccccc1)C2</smiles><smiles>N#Cc1cc2c(nc1N)CCN(Cc1ccccc1)C2</smiles><smiles>CC(C)(C)OC(=O)N1CCc2nc(N)nc(-c3ccccc3)c2C1</smiles>

Figure 2. Examples of 2-amino-5,6,7,8-tetrahydro-1,6-naphthyridine-3-carbonitriles reported in the literature.

As a starting point, a protocol described for the synthesis of certain 2-amino-4-aryl-3cyanopyridines was considered. ${ }^{5}$ The attractiveness of this synthetic choice lies in the fact that it consists of a one pot procedure, involving the condensation of malononitrile with aromatic aldehydes and alkyl ketones in the presence of ammonium acetate. To the best of our knowledge, no $N$-substituted-4-piperidones have been tested under these conditions (Equation 1). Regarding our interest in obtaining 2-amino-4-phenyl-5,6,7,8-tetrahydro-1,6-naphthyridine-3-carbonitriles, we decided to study the scope of the above mentioned method.

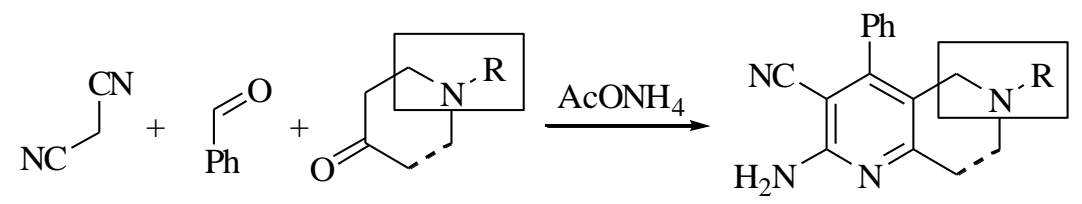




\section{Results and Discussion}

Figure 3 shows the piperidones 8-10 selected as the carbonyl partners. Whereas 1benzylpiperidin-4-one $\mathbf{8}$ is commercially available, 1-(prop-2-ynyl)piperidin-4-one $\mathbf{9}^{6}$ and tertbutyl 4-oxopiperidine-1-carboxylate $\mathbf{1 0}^{7}$ were synthesized from piperidin-4-one 11 (see Supporting Information).

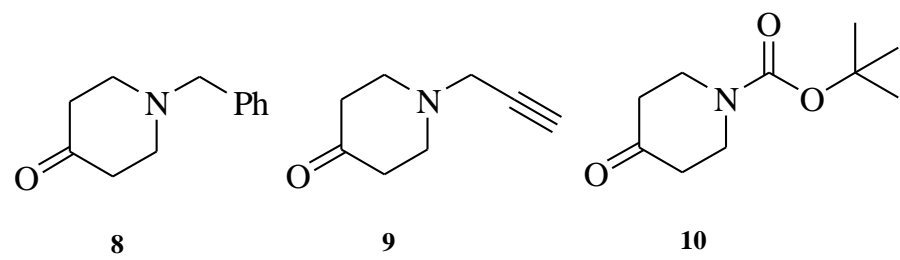

Figure 3. Selected ketones for the synthesis of 2-amino-4-phenyl-5,6,7,8-tetrahydro-1,6naphthyridine-3-carbonitriles.

A preliminary trial carried out under the experimental conditions reported for other aminoketones $^{5}$ gave rise to the desired 2-amino-6-benzyl-4-phenyl-5,6,7,8-tetrahydro-1,6naphthyridine-3-carbonitrile 1 (Figure 1) when mixing malononitrile, benzaldehyde, 8 and ammonium acetate, albeit in low chemical yield $(21 \%) .{ }^{8}$ With the aim of improving the yield, we decided to prepare 2-benzylidenemalononitrile $\mathbf{1 2}$ beforehand and add in situ piperidone 8; the isolated precipitate was then further treated with an $\mathrm{AcONH}_{4} / \mathrm{AcOH}$ mixture. ${ }^{9}$ Surprisingly, 6amino-2-benzyl-8-phenyl-1,2,3,4-tetrahydroisoquinoline-5,7-dicarbonitrile 13 (Scheme 1) and not compound 1 was obtained under these conditions. Although the ${ }^{1} \mathrm{H}-\mathrm{NMR}$ spectra are very similar for both molecules, ${ }^{13} \mathrm{C}-\mathrm{NMR}$ was conclusive; in the case of $\mathbf{1 3}$, two signals at 115.6 and $115.2 \mathrm{ppm}$ and two additional signals at 96.6 and $96.4 \mathrm{ppm}$ account for two nitrile carbons atoms $(\mathrm{CN})$ and two aromatic carbons bearing the nitrile groups $(C-\mathrm{CN})$ respectively. The mass spectrum supported the proposed structure, showing a main peak at $365.2(\mathrm{M}+1)$. The formation of this product can be rationalized as shown in Scheme 1:10 if ammonium acetate is not present but piperidone is, both formation of intermediate II and subsequent condensation with malononitrile take place; due to the reversibility of the initial benzaldehyde-malononitrile condensation, the presence of malononitrile would be guaranteed even though an excess of this reagent was not used.

Continuing with our efforts to improve the yield of product $\mathbf{1}$, an alternative stepwise protocol $^{5}$ was considered. Compound $\mathbf{1 2}$ was prepared and isolated; then, reaction with $\mathbf{8}$ and $\mathrm{AcONH}_{4}$ in toluene was performed. By adding compound $\mathbf{8}$ and $\mathrm{AcONH}_{4}$ at the same time, intermediate II formed upon reaction between $\mathbf{1 2}$ and $\mathbf{8}$ evolved to give rise compound 1; moreover, a better yield of $46 \%$ was obtained when following this stepwise protocol. 


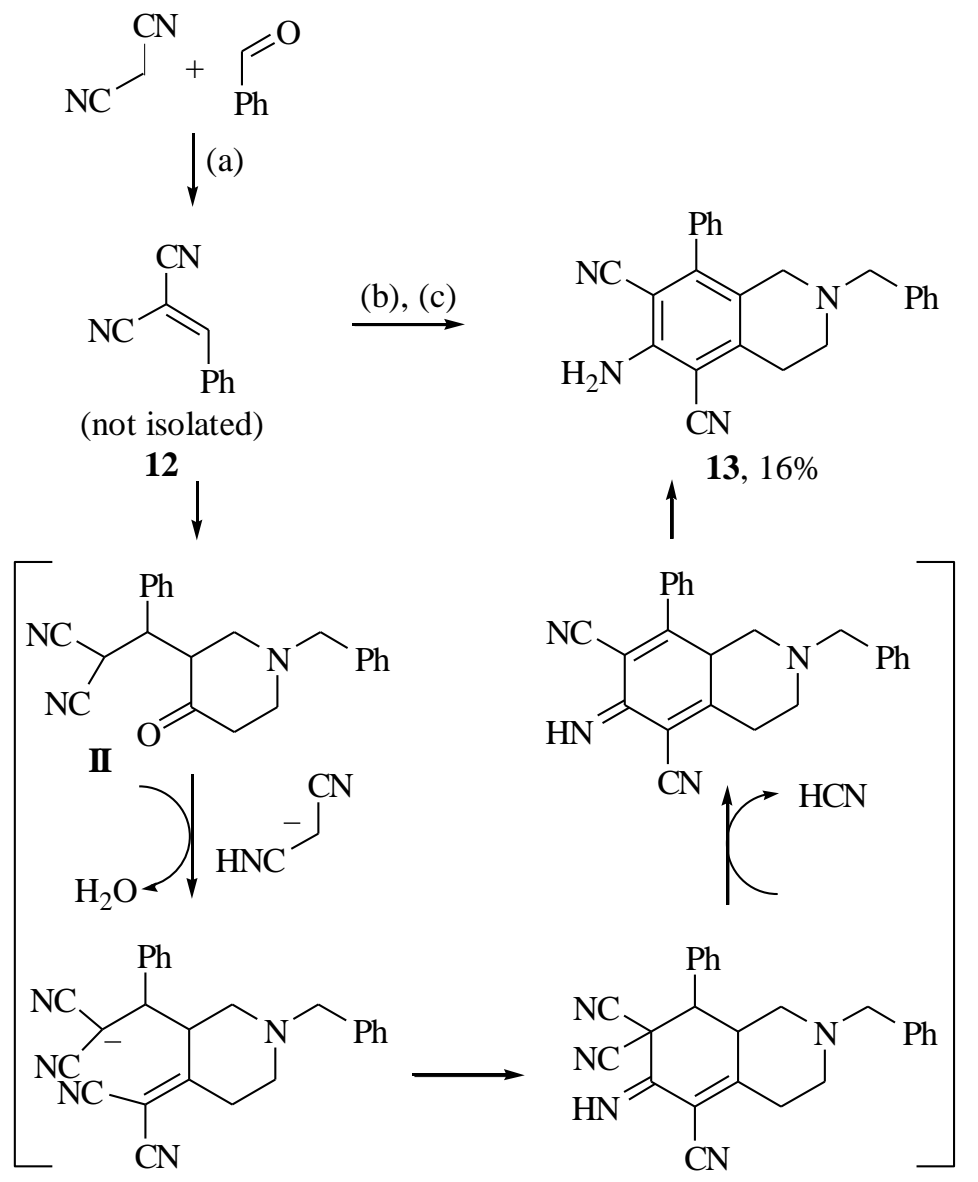

Scheme 1. Reaction conditions and mechanism of the formation of compound 13: (a) piperidine (cat.), toluene, rt; (b) piperidone 8; (c) $\mathrm{AcONH}_{4} / \mathrm{AcOH}$ reflux.

Besides tetrahydronaphthyridine 1, 2-benzylmalononitrile could be isolated from the crude mixture in $40 \%$ yield. This fact indicates that a side reaction is occuring, consisting of the reduction of starting 2-benzylidenemalononitrile. Thus, an additional trial to improve the yield of 1 was carried out by doubling the amount of this reagent (Scheme 2). In this way, the yield of isolated product 1 was increased up to $68 \%$. Further experiments considering larger amounts of starting 12 were performed, although no significant improvement was achieved.

In a similar fashion, we applied this protocol to the reaction of piperidone 9 with 2 equivalents of 2-benzylidenemalonitrile in the presence of $\mathrm{AcONH}_{4}$ and toluene as solvent. The formation of 2-amino-4-phenyl-6-(prop-2-ynyl)-5,6,7,8-tetrahydro-1,6-naphthyridine-3carbonitrile 2 was confirmed and the initial yield of 15\% significantly increased to $45 \%$ (Scheme 2). On the contrary, derivative $\mathbf{3}$ (Figure 1) was not detected in the reaction with piperidone $\mathbf{1 0}$ even under these optimized conditions. 


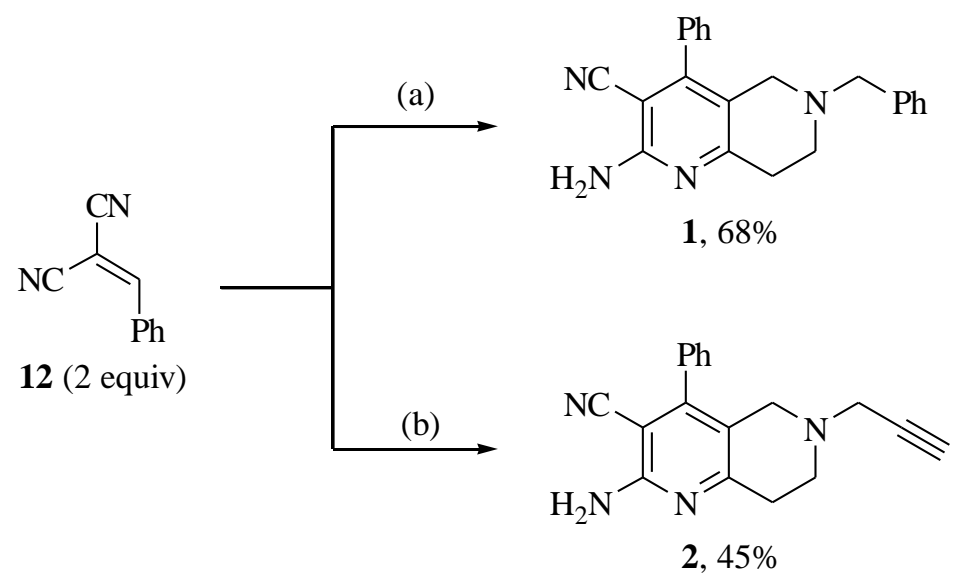

Scheme 2. Optimized method for the synthesis of compounds 1 and 2. Conditions: (a) piperidone 8, $\mathrm{AcONH}_{4}$, toluene, reflux; (b) piperidone 9, $\mathrm{AcONH}_{4}$, toluene, reflux.

So far, the experiments described just involved $N$-substituted 4-piperidones, and consequently, the regioselectivity of the reaction was not an issue. We then decided to study the outcome of the reaction when using methylalkylketones such as $\beta$-aminoketone 14 (Scheme 3). The latter was readily synthesized by a Michael-type reaction of but-3-en-2-one and $N$ methylpropargylamine in almost quantitative chemical yield (Scheme 3). Under the improved experimental conditions above described for $\mathbf{1}$ and $\mathbf{2}$, the reaction gave rise to a complex mixture, from which only compound 15 could be isolated, in poor yield (14\%). ${ }^{11}$ The structure of this product was confirmed on the basis of its analytical and spectroscopic data as well as by Xray diffraction analysis (Figure 4). ${ }^{12}$ Surprisingly, 2-butanone reacts with 2benzylidenemalonitrile to give exclusively 2 -amino-5,6-dimethyl-4-phenylnicotinonitrile in $65 \%$ yield. ${ }^{5}$ Thus, the aminated fragment seems to be playing a role; steric effects might justify the observed result.

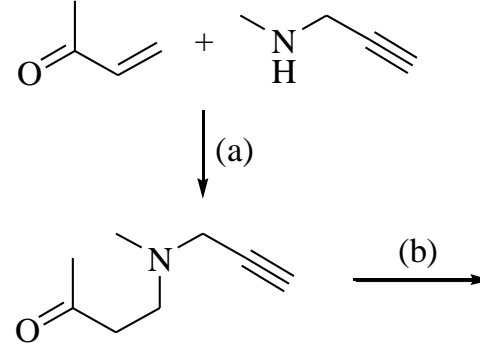

$14,99 \%$<smiles>C#CCN(C)CCc1cc(-c2ccccc2)c(C#N)c(N)n1</smiles>

$15,14 \%$

Scheme 3. Preparation of $\beta$-aminoketone 14 and transformation into the unexpected 2-amino-3cyanopyridine 15. Conditions: (a) toluene, reflux; (b) reagent 12, $\mathrm{AcONH}_{4}$, toluene, reflux. 


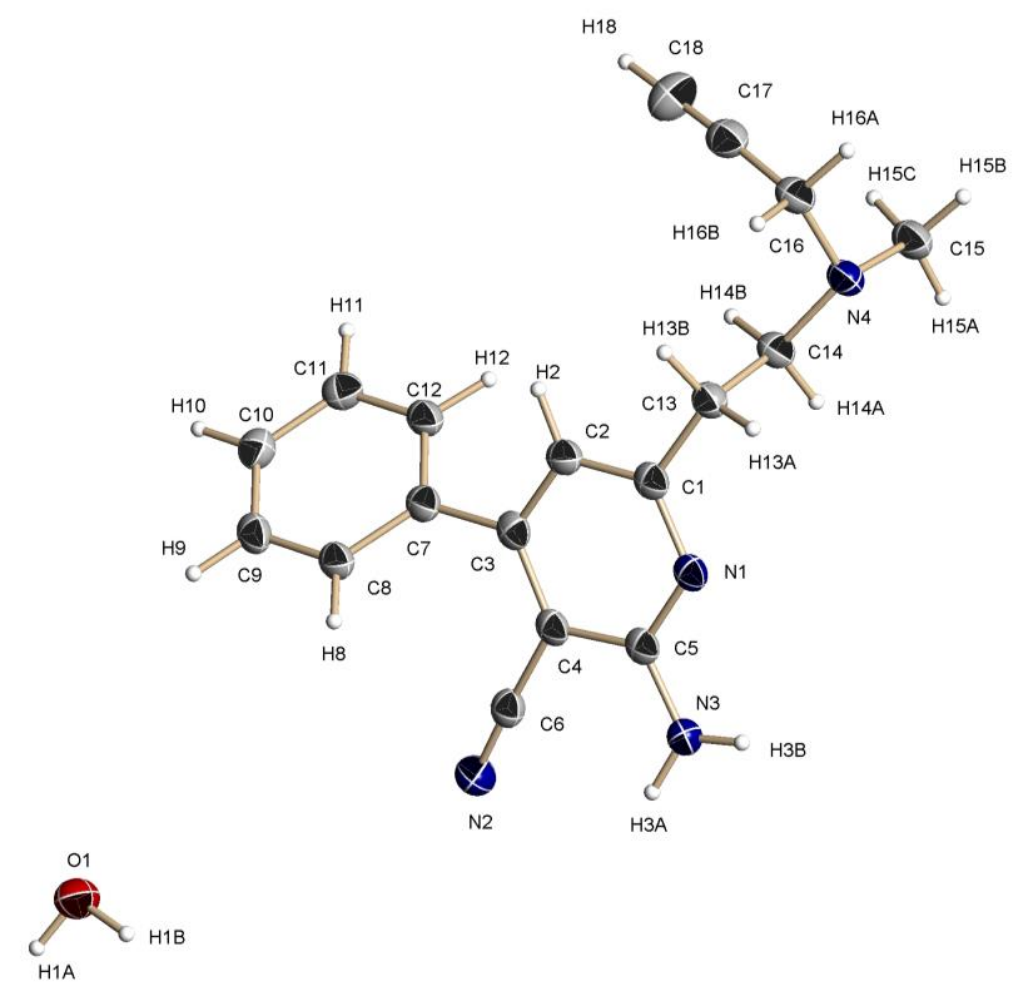

Figure 4. X-ray diffraction analysis of compound 15.

As the observed regioselectivity in the previous example was not the one leading to nicotinic derivatives, we tried to control the regioselectivity by increasing the acidity of the required proton atoms in the carbonylic reagent. 1,3-dicarbonylic compound $\mathbf{1 6}^{13}$ (Figure 5) was then prepared and tested under the above mentioned optimized conditions. The reaction turned out to give a high degree of decomposition and no defined products could be detected. At this point, we decided to follow an alternative synthetic method to prepare 6-amino-5-cyano-2-methyl-4phenyl- $N$-(prop-2-ynyl)nicotinamide $\mathbf{1 7}$ as shown in scheme 4. According to this, tert-butyl acetoacetate was chosen as the 1,3-dicarbonylic compound. ${ }^{14}$ Under the optimized conditions previously described, expected tert-butyl 6-amino-5-cyano-2-methyl-4-phenylpyridine-3carboxylate 18 was isolated in $41 \%$ yield. Removal of the tert-butyl group and subsequent amide formation with $\mathrm{N}$-propargylamine and $\mathrm{EDCI} / \mathrm{HOBt}$ provided us with the required nicotinamide in $29 \%$ yield (from starting $\mathbf{1 8}$ ).<smiles>C#CCN(C)C(=O)CC(C)=O</smiles>

16

\section{Figure 5}




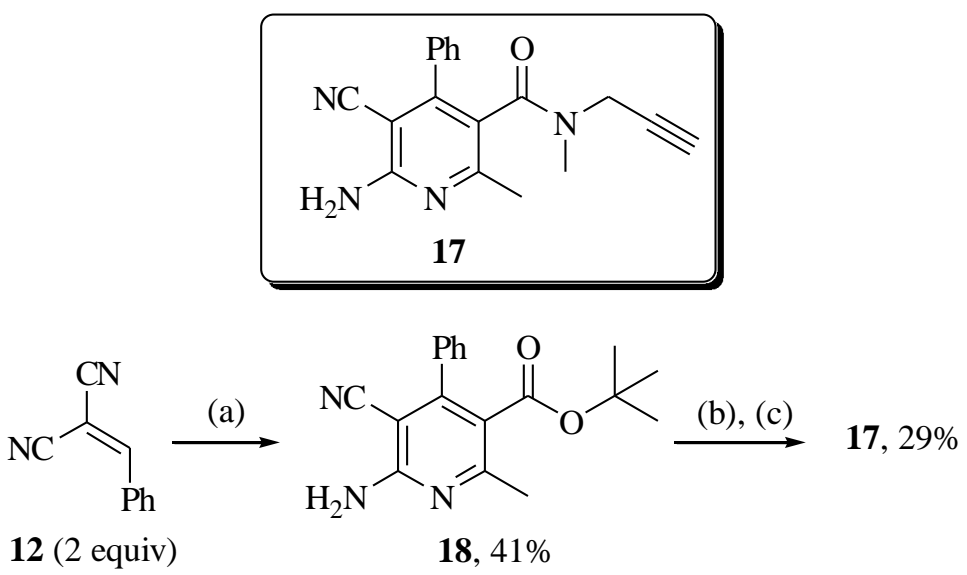

Scheme 4. Alternative way to prepare nicotinamide 17. Conditions: (a) tert-butyl acetoacetate, AcONH 4 , toluene, reflux; (b) i) TFA, $\mathrm{CH}_{2} \mathrm{Cl}_{2}, \mathrm{rt}, 7$ days ii) $\mathrm{NaOH} 2 \mathrm{~N}$; c) EDCI, DIPEA, HOBt, $N$-methylpropargylamine, $\mathrm{CH}_{2} \mathrm{Cl}_{2}, 0^{\circ} \mathrm{C}$ to rt, $12 \mathrm{~h}$.

For comparison, a trial of preparation of compound $\mathbf{1 8}$ in a one-pot fashion was carried out by mixing malononitrile, benzaldehyde, tert-butyl acetoacetate and ammonium acetate in methanol. Decomposition was observed in this case too and just a $4 \%$ of compound 19 (Figure 6) could be isolated. On the other hand, an attempt of obtaining compound $\mathbf{1 8}$ from the pyrane precursor 20 (Figure 6) ) $^{914}$ gave rise to pyridine 21 (Figure 6), which implied a decarboxylation process taking place. These facts showed again that slight variations of the protocol afforded quite different compounds.

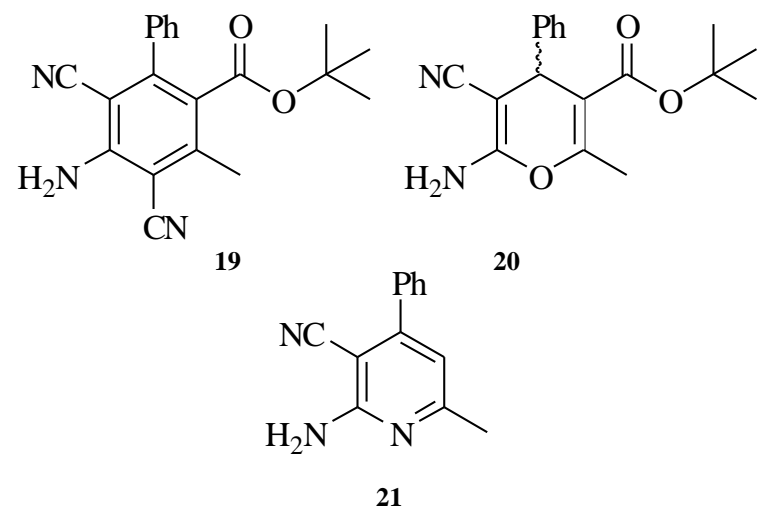

Figure 6

\section{Conclusions}

To sum up, this is the first time that a simple method based on four components is used for the preparation of 2-amino-3-cyano-4-phenylnicotinic compounds. The previously described 
synthesis of 2-amino-4-aryl-3-cyanopyridines inspired us to prepare the required tetrahydro-1,6naphthyridines $\mathbf{1}$ and $\mathbf{2}$. A slight modification of the protocol afforded tetrahydroisoquinoline $\mathbf{1 3}$ instead of the required 1. Mechanistical explanations for the high dependence on the followed procedure in the preparation of nicotinic compounds from four components have been provided. Moreover, unexpected regiochemistry was observed when employing $\beta$-aminoketone 14. In order to obtain the desired regiochemistry, tert-butyl acetoacetate was used as the carbonylic reagent and intermediate $\mathbf{1 8}$ was succesfully prepared. Finally, subsequent modification of the latter afforded nicotinamide 17.

\section{Experimental Section}

General. Unless otherwise stated, all reagents were purchased from commercial sources (Aldrich, Fluka) and used without further purification. Anhydrous toluene was obtained by passing the solvent through an activated alumina column on a PureSolv ${ }^{\mathrm{TM}}$ solvent purification system (Innovative Technologies, Inc., MA). Flash column chromatography was carried out using silica gel C60 (230 mesh) as the stationary phase. Analytical thin layer chromatography was performed on $0.25 \mathrm{~mm}$ thick precoated silica gel plates $\left(60 \mathrm{~F}_{254}\right)$. Compounds were visualized under UV light at $254 \mathrm{~nm}$ or either staining with a $1 \%$ ninhydrin in $\mathrm{EtOH}$ solution or with cerium molybdate. ${ }^{1} \mathrm{H}$ NMR and ${ }^{13} \mathrm{C}$ NMR spectra were recorded at room temperature in $\mathrm{CDCl}_{3}$ or $\mathrm{d}_{6}$-DMSO, at 300,400 or $500 \mathrm{MHz}$ and at 75,100 or $125 \mathrm{MHz}$, respectively, using solvent peaks $(7.26(H), 77.2(C)$ ppm) as internal reference. The assignment of chemical shifts is based on standard NMR experiments $\left({ }^{1} \mathrm{H},{ }^{13} \mathrm{C}-\mathrm{DEPT},{ }^{1} \mathrm{H},{ }^{1} \mathrm{H}-\mathrm{COSY}\right.$, gHSQC, gHMBC). Melting points were determined on a microscope type apparatus and are uncorrected. Mass spectra (EI, ES) were carried out by the mass spectrometry services at CQO (CSIC, Spain), as well as elemental analysis.

2-Amino-6-benzyl-4-phenyl-5,6,7,8-tetrahydro-1,6-naphthyridine-3-carbonitrile $\mathrm{AcONH}_{4}(116 \mathrm{mg}, 1.5 \mathrm{mmol})$, dry toluene $(3 \mathrm{~mL})$, benzylidenemalononitrile (308 $\left.\mathrm{mg}, 2 \mathrm{mmol}\right)$ and $N$-benzyl-piperidin-4-one 8 (189 $\mathrm{mg}, 1 \mathrm{mmol})$ were mixed and heated under reflux for $4 \mathrm{~h}$ in a Dean-Stark system. Solvents were then removed in vacuum and the resulting residue purified by flash column chromatography (30\% ethyl acetate in hexane, then $40 \%$ and finally $50 \%$ ) yielding the titled compound $(231 \mathrm{mg}, 68 \%)$ as a colorless solid.

Mp 193-195 ${ }^{\circ} \mathrm{C}$. IR (KBr): 3457, 3342, 3221, 2937, 2819, 2764, 2220, 1627, 1564, 1496, 1456, 1430, 1365, $1247 \mathrm{~cm}^{-1} .{ }^{1} \mathrm{H}$ NMR $\left(\mathrm{CDCl}_{3}, 400 \mathrm{MHz}\right): \delta=7.42-7.34(\mathrm{~m}, 3 \mathrm{H}, \mathrm{ArH}), 7.25-7.12(\mathrm{~m}$, $7 \mathrm{H}, \mathrm{ArH}$ ), 5.19 (br s, 2H, NH ), 3.47 (s, 2H, $\mathrm{NCH}_{2} \mathrm{CCH}$ ), 3.23 (s, 2H, $\mathrm{CCCH}_{2} \mathrm{~N}$ ), 2.81 (t, $J=6.0$ $\left.\mathrm{Hz}, 2 \mathrm{H}, \mathrm{CH}_{2} \mathrm{CH}_{2} \mathrm{~N}\right), 2.62\left(\mathrm{t}, J=6.0 \mathrm{~Hz}, 2 \mathrm{H}, \mathrm{CH}_{2} \mathrm{CH}_{2} \mathrm{~N}\right) \mathrm{ppm} .{ }^{13} \mathrm{C} \mathrm{NMR}\left(\mathrm{CDCl}_{3}, 100 \mathrm{MHz}\right): \delta=$ 159.4, 157.9, 153.0, 137.8, 135.1 (C), 129.3, 129.1, 128.9, 128.4, 128.0, $127.3(\mathrm{CH}), 119.0$, 116.6, 90.0 (C), 62.3, 54.0, 49.1, 33.1 ppm. MS (ES): $\mathrm{m} / \mathrm{z}(\%)=341.2 / 342.3 / 343.2[\mathrm{M}+1]^{+}$. Anal. Calcd for $\mathrm{C}_{22} \mathrm{H}_{20} \mathrm{~N}_{4}$ : C, 77.62; H, 5.92; N, 16.46; found C, 77.48; H, 6.05; N, 16.22. 
2-Amino-4-phenyl-6-(prop-2-ynyl)-5,6,7,8-tetrahydro-1,6-naphthyridine-3-carbonitrile (2). Procedure as above described for compound 1. Starting from $137 \mathrm{mg}$ (1 mmol) of 9, $130 \mathrm{mg}$ $(45 \%)$ of the titled compound were obtained after flash column chromatography (30\% ethyl acetate in hexane, then $40 \%, 50 \%$ and finally $60 \%$ ) as a yellowish solid.

Mp 163-165 ${ }^{\circ} \mathrm{C}$. IR (KBr): 3418, 3302, 3180, 2911, 2818, 2787, 2211, 1641, 1561, 1464, 1435 , 1376, 1253, 1142, 734, 702, 662, $638 \mathrm{~cm}^{-1} .{ }^{1} \mathrm{H} \mathrm{NMR}\left(\mathrm{CDCl}_{3}, 300 \mathrm{MHz}\right): \delta=7.53-7.33(\mathrm{~m}, 3 \mathrm{H}$, ArH), 7.29-7.11 (m, 2H, ArH), 5.18 (br s, 2H, $\mathrm{NH}_{2}$ ), 3.32 (br s, 2H, $\mathrm{NCH}_{2} \mathrm{CCH}$ ), 3.25 (br s, 2H, $\mathrm{NCCCH}_{2} \mathrm{~N}$ ), 2.98-2.86 (m, 2H, $\left.\mathrm{CH}_{2} \mathrm{CH}_{2} \mathrm{~N}\right), 2.86-2.74\left(\mathrm{~m}, 2 \mathrm{H}, \mathrm{CH}_{2} \mathrm{CH}_{2} \mathrm{~N}\right), 2.16(\mathrm{~s}, 1 \mathrm{H}, \mathrm{CCH})$ ppm. ${ }^{13} \mathrm{C} \mathrm{NMR}\left(\mathrm{CDCl}_{3}, 75 \mathrm{MHz}\right): \delta=158.7,157.8,153.2,135.1(\mathrm{C}), 129.4,129.0,128.0(\mathrm{CH})$, 118.6, 116.5, 90.2, $78.1(\mathrm{C}), 73.8(\mathrm{CH}), 51.8,49.0,46.6,33.2\left(\mathrm{CH}_{2}\right) \mathrm{ppm} . \mathrm{MS}(\mathrm{ES}): \mathrm{m} / \mathrm{z}(\%)=$ 289.2/290.3/291.3 [M+1] $]^{+}$. Anal. Calcd for $\mathrm{C}_{18} \mathrm{H}_{16} \mathrm{~N}_{4}$ : C, 74.98; H, 5.59; N, 19.43. Found: C, 74.79; H, 5.46; N, 19.24.

$N$-Propargyl-piperidin-4-one (9). ${ }^{6}$ A suspension of 4-piperidone hydrochloride 11 (172 mg, 1 mmol) in THF $(12 \mathrm{~mL})$ was treated with DIPEA $(0.17 \mathrm{~mL}, 1 \mathrm{mmol})$ and $\mathrm{tBuNH}_{2}(0.26 \mathrm{~mL}, 2.5$ $\mathrm{mmol})$. The mixture was cooled in an ice-bath and then propargyl bromide $(0.09 \mathrm{~mL}, 1 \mathrm{mmol})$ was carefully added. The reaction was kept overnight while reaching rt. The precipitate was filtered off and washed with $\mathrm{Et}_{2} \mathrm{O}(6 \times 10 \mathrm{~mL})$, the filtrate concentrated and the resulting residue purified by flash column chromatography. The product (106 mg, 77\%) was obtained as a yellowish oil.

${ }^{1} \mathrm{H} \mathrm{NMR}\left(\mathrm{CDCl}_{3}, 300 \mathrm{MHz}\right): \delta=3.41\left(\mathrm{~d}, J=2.4 \mathrm{~Hz}, 2 \mathrm{H}, \mathrm{CH}_{2} \mathrm{CCH}\right), 2.84(\mathrm{t}, J=6.2 \mathrm{~Hz}, 4 \mathrm{H}$, $\left.2 \times \mathrm{CH}_{2} \mathrm{CH}_{2} \mathrm{~N}\right), 2.46\left(\mathrm{t}, J=6.2 \mathrm{~Hz}, 4 \mathrm{H}, 2 \times \mathrm{CH}_{2} \mathrm{CH}_{2} \mathrm{~N}\right), 2.27\left(\mathrm{t}, J=2.4 \mathrm{~Hz}, 1 \mathrm{H}, \mathrm{CH}_{2} \mathrm{CCH}\right) \mathrm{ppm}$.

tert-Butyl-4-oxopiperidin- $\boldsymbol{N}$-carboxylate (10). ${ }^{7}$ A suspension of reagent $11(1.72 \mathrm{~g}, 10 \mathrm{mmol})$ in $\mathrm{CHCl}_{3}(20 \mathrm{~mL})$ was treated at $0{ }^{\circ} \mathrm{C}$ with $\mathrm{K}_{2} \mathrm{CO}_{3}(2.76 \mathrm{~g}, 20 \mathrm{mmol}), \mathrm{Boc}_{2} \mathrm{O}(2.25 \mathrm{~g}, 10.3 \mathrm{mmol})$ and $\mathrm{NEt}_{3}(1.39 \mathrm{~mL}, 10 \mathrm{mmol})$. The stirring was kept overnight while reaching rt. Water $(20 \mathrm{~mL})$ and $\mathrm{CH}_{2} \mathrm{Cl}_{2}(40 \mathrm{~mL})$ were then added, layers separated and the organic fraction was further washed with water $(2 \times 40 \mathrm{~mL}), \mathrm{HCl} 1 \mathrm{~N}(3 \times 40 \mathrm{~mL})$ and $\mathrm{NaOH} 1 \mathrm{~N}(3 \times 40 \mathrm{~mL})$. Solvents were removed in vacuo to give $\mathbf{1 0}$ as a colorless solid $(1.89 \mathrm{~g}, 95 \%)$, m.p. $68-70{ }^{\circ} \mathrm{C}$ (lit. $\left.72{ }^{\circ} \mathrm{C}\right)$.

\section{6-Amino-2-benzyl-8-phenyl-1,2,3,4-tetrahydroisoquinoline-5,7-dicarbonitrile (13). A} solution of benzaldehyde $(0.1 \mathrm{~mL}, 1 \mathrm{mmol})$ in dry toluene $(2.5 \mathrm{~mL})$ under argon was treated with malononitrile $(66.1 \mathrm{~mL}, 1 \mathrm{mmol})$ and then piperidine $(0.01 \mathrm{~mL}, 0.1 \mathrm{mmol})$ was slowly added. The solution gradually became cloudy while a brownish oil appeared. After $12 \mathrm{~h}$ of stirring at $\mathrm{rt}$, piperidone $8(147.6 \mathrm{mg}, 0.78 \mathrm{mmol})$ and further piperidine $(0.01 \mathrm{~mL}, 0.1 \mathrm{mmol})$ were added. After $6 \mathrm{~h}$, the precipitate was collected by filtration, washed with cold toluene $(6 \times 5 \mathrm{~mL})$ and dried under vacuum. $\mathrm{AcONH}_{4}(107 \mathrm{mg}, 1.39 \mathrm{mmol})$ was dissolved in $\mathrm{AcOH}(1.7 \mathrm{~mL})$ while heating. The previously obtained precipitate was then added and the mixture refluxed for $10 \mathrm{~h}$. After this time, TLC showed the formation of a sole product. Solvent was partially removed in vacuum and the resulting oil was treated with sat. $\mathrm{NaHCO}_{3}(20 \mathrm{~mL})$ and extracted with ethyl acetate $(3 \times 20 \mathrm{~mL})$. The organic fractions were dried $\left(\mathrm{MgSO}_{4}\right)$ and concentrated, giving rise to a colorless solid (45.5 mg, 16\% from starting ketone). 
${ }^{1} \mathrm{H}$ NMR $\left(\mathrm{CDCl}_{3}, 400 \mathrm{MHz}\right): \delta=7.42-7.36(\mathrm{~m}, 3 \mathrm{H}, \mathrm{ArH}), 7.24-7.11(\mathrm{~m}, 7 \mathrm{H}, \mathrm{ArH}), 5.02(\mathrm{br}$, $\left.2 \mathrm{H}, \mathrm{NH}_{2}\right), 3.45\left(\mathrm{~s}, 2 \mathrm{H}, \mathrm{NCH}_{2} \mathrm{Ph}\right), 3.16\left(\mathrm{~s}, 2 \mathrm{H}, \mathrm{CCH}_{2} \mathrm{~N}\right), 2.95\left(\mathrm{t}, J=5.9 \mathrm{~Hz}, 2 \mathrm{H}, \mathrm{CH}_{2} \mathrm{CH}_{2} \mathrm{~N}\right), 2.59$ $\left(\mathrm{t}, J=6.0 \mathrm{~Hz}, 2 \mathrm{H}, \mathrm{CH}_{2} \mathrm{CH}_{2} \mathrm{~N}\right) \mathrm{ppm} .{ }^{13} \mathrm{C} \mathrm{NMR}\left(\mathrm{CDCl}_{3}, 100 \mathrm{MHz}\right): \delta=150.2,148.7,144.9$, 137.4, $135.8(\mathrm{C}), 129.3,129.1,129.0,128.5,128.2,127.4(\mathrm{CH}), 124.4,115.6,115.2,96.6,96.4$ (C), 62.2, 54.5, 48.3, $29.6\left(\mathrm{CH}_{2}\right)$ ppm. MS (ES): $m / z(\%)=365.2 / 366.3[\mathrm{M}+1]^{+}$.

4-( $N$-Methyl- $\boldsymbol{N}$-propargylamino)-butan-2-one (14). $N$-Methylprop-2-yn-1-amine $(1.7 \mathrm{~mL}, 20$ $\mathrm{mmol})$ and toluene $(20 \mathrm{~mL})$ were charged in a flask fitted with a reflux condenser under argon. But-3-en-2-one $(2.3 \mathrm{~mL}, 28 \mathrm{mmol})$ was dropwise added at $\mathrm{rt}$ and the mixture heated at reflux for 4h. $\mathrm{HCl} 1 \mathrm{~N}$ was then added up to $\mathrm{pH}=1$ and after addition of $\mathrm{Et}_{2} \mathrm{O}(20 \mathrm{~mL})$, layers were separated, the aqueous one being treated with further $\mathrm{Et}_{2} \mathrm{O}(2 \times 20 \mathrm{~mL})$. The aqueous fractions were basified to $\mathrm{pH}=8$ and extracted with $\mathrm{CH}_{2} \mathrm{Cl}_{2}(3 \times 50 \mathrm{~mL})$, the organic fractions dried $\left(\mathrm{MgSO}_{4}\right)$, filtrated and concentrated. The resulting brown oil $(2.63 \mathrm{~g}, 94 \%)$ was used without further purification.

IR (KBr): 3286, 2946, 2098, 1712, 1358, $1165 \mathrm{~cm}^{-1} .{ }^{1} \mathrm{H} \mathrm{NMR}\left(\mathrm{CDCl}_{3}, 300 \mathrm{MHz}\right): \delta=3.32(\mathrm{~d}$, $\left.J=2.4 \mathrm{~Hz}, 2 \mathrm{H}, \mathrm{CH}_{2} \mathrm{CCH}\right), 2.72\left(\mathrm{t}, J=7.0 \mathrm{~Hz}, 2 \mathrm{H}, \mathrm{CH}_{2} \mathrm{CH}_{2} \mathrm{~N}\right), 2.58(\mathrm{t}, J=7.0 \mathrm{~Hz}, 2 \mathrm{H}$, $\left.\mathrm{CH}_{2} \mathrm{CH}_{2} \mathrm{~N}\right), 2.29\left(\mathrm{~s}, 3 \mathrm{H}, \mathrm{CH}_{3} \mathrm{~N}\right), 2.21\left(\mathrm{t}, J=2.4 \mathrm{~Hz}, 1 \mathrm{H}, \mathrm{CH}_{2} \mathrm{CCH}\right), 2.16\left(\mathrm{~s}, 3 \mathrm{H}, \mathrm{CH}_{3} \mathrm{CO}\right) \mathrm{ppm}$.

${ }^{13} \mathrm{C} \mathrm{NMR}\left(\mathrm{CDCl}_{3}, 75 \mathrm{MHz}\right): \delta=207.5,78.2(\mathrm{C}), 73.3(\mathrm{CH}), 50.0,45.5,41.8,41.6\left(\mathrm{CH}_{3}\right.$, $\left.3 \times \mathrm{CH}_{2}\right), 29.9\left(\mathrm{CH}_{3}\right)$ ppm. EM (ES): $m / z(\%)=140.2 / 141.2[\mathrm{M}+1]^{+}$.

2-Amino-6-(2-(methyl(prop-2-ynyl)amino)ethyl)-4-phenylnicotinonitrile (15). $\mathrm{AcONH}_{4}(115$ $\mathrm{mg}, 1.5 \mathrm{mmol})$, dry toluene (3 mL), 2-benzylidenemalononitrile 12 (308 mg, $2 \mathrm{mmol})$ and 4-(Nmethyl- $N$-propargylamino)-butan-2-one $14(137 \mathrm{mg}, 1 \mathrm{mmol})$ were mixed and heated under reflux for $4 \mathrm{~h}$ in a Dean-Stark system. Solvents were then removed in vacuum and the resulting residue purified by flash column chromatography (30\% ethyl acetate in hexane, then 40\%, 50\% and finally $60 \%$ ) yielding the titled compound (42 mg, 14\%) as a brown oil, that crystallized as a yellowish solid (from ethyl acetate).

Mp 114-116 ${ }^{\circ} \mathrm{C}$. IR (KBr): 3437, 3306, 3181, 2214, 1648, 1577, 1556, $1047 \mathrm{~cm}^{-1}$. ${ }^{1} \mathrm{H}$ NMR $\left(\mathrm{CDCl}_{3}, 400 \mathrm{MHz}\right): \delta=7.59-7.54(\mathrm{~m}, 2 \mathrm{H}, \mathrm{ArH}), 7.52-7.46(\mathrm{~m}, 3 \mathrm{H}, \mathrm{ArH}), 6.67(\mathrm{~s}, 1 \mathrm{H}, \mathrm{CHCN})$, 5.34 (br s, $2 \mathrm{H}, \mathrm{NH}_{2}$ ), 3.41 (d, $\left.J=2.3 \mathrm{~Hz}, 2 \mathrm{H}, \mathrm{NCH}_{2} \mathrm{CCH}\right), 2.84\left(\mathrm{~s}, 4 \mathrm{H}, \mathrm{CH}_{2} \mathrm{CH}_{2} \mathrm{~N}\right.$ ), 2.37 (s, 3H, $\left.\mathrm{CH}_{3} \mathrm{~N}\right), 2.24\left(\mathrm{t}, J=2.3 \mathrm{~Hz}, 1 \mathrm{H}, \mathrm{NCH}_{2} \mathrm{CCH}\right) \mathrm{ppm} .{ }^{13} \mathrm{C} \mathrm{NMR}\left(\mathrm{CDCl}_{3}, 100 \mathrm{MHz}\right): \delta=164.2$, 160.3, 154.7, $136.8(\mathrm{C}), 129.9,129.0,128.3(\mathrm{CH}), 117.2(\mathrm{C}), 113.8(\mathrm{CH}), 87.7,78.5(\mathrm{C}), 73.5$ $(\mathrm{CH})$, 54.8, $45.7\left(\mathrm{CH}_{2}\right), 41.9\left(\mathrm{CH}_{3}\right), 36.8\left(\mathrm{CH}_{2}\right)$ ppm. MS $(\mathrm{EI}): \mathrm{m} / \mathrm{z}(\%)=290.2 / 291.2 / 292.2$ $[\mathrm{M}]^{+}$. Anal. Calcd for $\mathrm{C}_{18} \mathrm{H}_{18} \mathrm{~N}_{4}$ : C, 74.46; H, 6.25; N, 19.30. Found: C, 74.19; H, 5.98; N, 19.43. $N$-Methyl- $N$-propargylacetoacetamide (16). ${ }^{13}$ tert-Butyl acetoacetate $(0.75 \mathrm{~mL}, 4.5 \mathrm{mmol})$ was diluted in toluene $(5 \mathrm{~mL})$ and $N$-methyl- $N$-propargylamine $(0.34 \mathrm{~mL}, 4.1 \mathrm{mmol})$ added. The mixture was refluxed for $14 \mathrm{~h}$ and then diluted in $\mathrm{Et}_{2} \mathrm{O}(20 \mathrm{~mL})$ after cooling. $\mathrm{HCl} 1 \mathrm{~N}(10 \mathrm{~mL})$ was then added and layers separated. The organic layer was treated with further $\mathrm{HCl} 1 \mathrm{~N}(2 \times 20$ $\mathrm{mL})$, the aqueous fractions combined, extracted once with $\mathrm{Et}_{2} \mathrm{O}(20 \mathrm{~mL})$ and basified with $\mathrm{NaOH}$ $50 \%$. When reaching $\mathrm{pH}=7-8$, the aqueous fraction was extracted with ethyl acetate $(3 \times 150 \mathrm{~mL})$. The organic fractions were separately dried $\left(\mathrm{Na}_{2} \mathrm{SO}_{4}\right)$ and filtered. The first organic fraction (obtained in $\mathrm{Et}_{2} \mathrm{O}$ ) showed a mixture of product and starting material and was purified by flash 
column chromatography (10\% ethyl acetate in hexane to $60 \%$ ), giving rise to $85 \mathrm{mg}$ of a yellowish oil; the second one (360 mg of a dark brownish oil, obtained in ethyl acetate) was used without further purification. Total yield: $71 \%$.

Mixture of rotamers. ${ }^{1} \mathrm{H}$ NMR $\left(\mathrm{CDCl}_{3}, 300 \mathrm{MHz}\right): \delta=4.21\left(\mathrm{~d}, J=2.4 \mathrm{~Hz}, 2 \mathrm{H}, \mathrm{CH}_{2} \mathrm{CCH}\right.$ of major rotamer), $4.00\left(\mathrm{~d}, J=2.3 \mathrm{~Hz}, 2 \mathrm{H}, \mathrm{CH}_{2} \mathrm{CCH}\right.$ of minor rotamer), $3.59\left(\mathrm{~s}, 2 \mathrm{H}, \mathrm{CH}_{2} \mathrm{CO}\right.$ of minor rotamer), 3.53 (s, $2 \mathrm{H}, \mathrm{CH}_{2} \mathrm{CO}$ of major rotamer), 3.02 (s, $3 \mathrm{H}, \mathrm{CH}_{3} \mathrm{~N}$ of major rotamer), $3.00\left(\mathrm{~s}, 3 \mathrm{H}, \mathrm{CH}_{3} \mathrm{~N}\right.$ of minor rotamer), 2.32 (t, $J=2.4 \mathrm{~Hz}, 1 \mathrm{H}, \mathrm{CCH}$ of minor rotamer), 2.26 (s, $3 \mathrm{H}, \mathrm{CH}_{3} \mathrm{CO}$ of minor rotamer), 2.25 (s, 3H, $\mathrm{CH}_{3} \mathrm{CO}$ of major rotamer), 2.22 (t, $J=2.5 \mathrm{~Hz}, 1 \mathrm{H}$, $\mathrm{CCH}$ of major rotamer) ppm.

6-Amino-5-cyano-2-methyl-4-phenyl- $N$-(prop-2-ynyl)nicotinamide (17). Compound 18 (193 $\mathrm{mg}, 0.62 \mathrm{mmol})$ was treated under argon at $\mathrm{rt}$ with $\mathrm{CH}_{2} \mathrm{Cl}_{2}(13 \mathrm{~mL})$ and TFA $(0.95 \mathrm{~mL})$. After 7 days, solvents were removed in vacuum and the residue was basified with $\mathrm{NaOH} 2 \mathrm{~N}(50 \mathrm{~mL})$. $\mathrm{CHCl}_{3}(30 \mathrm{~mL})$ was added until the observed solid was dissolved and layers were then separated. The aqueous layer was extracted with $\mathrm{CHCl}_{3}(2 \times 20 \mathrm{~mL})$. The organic fractions were washed once with $\mathrm{NaOH} 2 \mathrm{~N}(5 \mathrm{~mL})$ and with water $(10 \mathrm{~mL})$. The collected aqueous fractions were then acidified ( $\mathrm{pH} 3-4)$ by adding $\mathrm{HCl}$ conc. to $\mathrm{pH}=3-4$ and extracted with isopropanol- $\mathrm{CHCl}_{3}$ 1:3 $(3 \times 30 \mathrm{~mL})$. The organic fractions were dried over $\mathrm{MgSO}_{4}$ and solvents were evaporated to yield 6-amino-5-cyano-2-methyl-4-phenylpyridine-3-carboxylic acid (116 mg, 74\%), which was used without further purification.

Colorless solid. Mp 228-230 ${ }^{\circ} \mathrm{C} .{ }^{1} \mathrm{H}$ NMR (DMSO- $\left.d_{6}, 300 \mathrm{MHz}\right): \delta=7.51-7.44(\mathrm{~m}, 3 \mathrm{H}, \mathrm{ArH})$, 7.38-7.29 (m, 2H, ArH), 7.20 (br s, 2H, NH$), 2.40$ (s, 3H, $\left.\mathrm{CH}_{3}\right)$ ppm. EM (EI): $\mathrm{m} / z(\%)=$ 253.0/254.0/255.0 [M] $]^{+} ; 236.0 / 237.0[\mathrm{M}-17]^{+}$.

To a mixture of 6-amino-5-cyano-2-methyl-4-phenylpyridine-3-carboxylic acid (50.6 mg, 0.20 mmol) in $\mathrm{CH}_{2} \mathrm{Cl}_{2}(0.5 \mathrm{~mL})$ at $0{ }^{\circ} \mathrm{C}$, EDCI $(38.3 \mathrm{mg}, 0.20 \mathrm{mmol})$, DIPEA (40 $\left.\mu 1,0.24 \mathrm{mmol}\right), N$ propargylamine $(15 \mu \mathrm{l}, 0.24 \mathrm{mmol})$ and $\mathrm{HOBt}(27 \mathrm{mg}, 0.20 \mathrm{mmol})$ were added. Stirring was kept overnight while the mixture reached rt. Water $(10 \mathrm{~mL})$ and further $\mathrm{CH}_{2} \mathrm{Cl}_{2}(15 \mathrm{~mL})$ were then added. Layers were separated and the organic layer was washed with water $(5 \mathrm{~mL})$ and sat. $\mathrm{NaHCO}_{3}(3 \times 10 \mathrm{~mL})$ and dried $\left(\mathrm{MgSO}_{4}\right)$. Solvents were removed in vacuum and the resulting residue was purified by flash column chromatography ( $1 \%$ to $2.5 \% \mathrm{MeOH}$ in $\mathrm{CH}_{2} \mathrm{Cl}_{2}$ ) to yield the titled compound $\mathbf{1 7}(22.4 \mathrm{mg}, 39 \%)$ as a white-off solid.

Mp 178-180 ${ }^{\circ} \mathrm{C}$. IR (KBr): 3393, 3332, 3288, 3178, 2219, 1665, 1641, 1561, 1290, 1252, 761, $706,648,529 \mathrm{~cm}^{-1} .{ }^{1} \mathrm{H}$ NMR (DMSO- $\left.d_{6}, 300 \mathrm{MHz}\right): \delta=8.61(\mathrm{t}, J=5.4 \mathrm{~Hz}, 1 \mathrm{H}, \mathrm{NH}), 7.47-7.39$ (m, 3H, ArH), 7.38-7.30 (m, 2H, ArH), 7.06 (s, 2H, NH$), 3.72\left(\mathrm{dd}, J=5.4,2.1 \mathrm{~Hz}, 2 \mathrm{H}, \mathrm{NCH}_{2}\right)$, $3.00(\mathrm{t}, J=2.1 \mathrm{~Hz}, 1 \mathrm{H}, \mathrm{CCH}), 2.30\left(\mathrm{~s}, 3 \mathrm{H}, \mathrm{CH}_{3}\right) \mathrm{ppm} .{ }^{13} \mathrm{C} \mathrm{NMR}\left(\mathrm{DMSO}-d_{6}, 75 \mathrm{MHz}\right): \delta=$ 166.3, 159.6, 158.7, 152.0, 135.4 (C), 129.0, 128.3, $128.2(\mathrm{CH}), 122.0,116.4,86.6,80.2$ (C), $73.0(\mathrm{CH}), \quad 28.0\left(\mathrm{CH}_{2}\right), 22.6\left(\mathrm{CH}_{3}\right)$ ppm. $\mathrm{EM}(\mathrm{EI}): \mathrm{m} / \mathrm{z}(\%)=290.1 / 291.1 \quad[\mathrm{M}]^{+}$; 236.1/237.1/238.1 [M-54] ${ }^{+}$. Anal. Calcd for $\mathrm{C}_{17} \mathrm{H}_{14} \mathrm{~N}_{4} \mathrm{O}$ : C, 70.33; H, 4.86; N, 19.30. Found: C, $70.11 ; \mathrm{H}, 4.91 ; \mathrm{N}, 19.54$. 
tert-Butyl 6-amino-5-cyano-2-methyl-4-phenylpyridine-3-carboxylate (18). $\mathrm{AcONH}_{4}(116$ $\mathrm{mg}, 1.5 \mathrm{mmol})$, dry toluene $(3 \mathrm{~mL})$, benzylidenemalononitrile $(308.3 \mathrm{mg}, 2 \mathrm{mmol})$ and tert-butyl acetoacetate $(0.17 \mathrm{~mL}, 1 \mathrm{mmol})$ were mixed and heated under reflux for $4 \mathrm{~h}$ in a Dean-stark system. Solvents were then removed in vacuum and the resulting residue purified by flash column chromatography (5\% ethyl acetate in hexane, then $10 \%, 20 \%$ and finally $30 \%$ ) yielding the titled compound (126 $\mathrm{mg}, 41 \%$ ) as a colorless solid.

Mp 215-217 ${ }^{\circ} \mathrm{C}$. IR (KBr): 3399, 3331, 3149, 3064, 3002, 2972, 2931, 2220, 1703, 1660, 1552 , 1498, 1476, 1447, 1367, 1299, 1257, 1150, 1076, 865, 844, 811, 798, 759, 742, 699, $563 \mathrm{~cm}^{-1}$.

${ }^{1} \mathrm{H}$ NMR $\left(\mathrm{CDCl}_{3}, 400 \mathrm{MHz}\right): \delta=7.48-7.43\left(\mathrm{~m}, 3 \mathrm{H}, \mathrm{ArH}_{\text {meta }}, \mathrm{ArH}_{\text {para }}\right), 7.38-7.32(\mathrm{~m}, 2 \mathrm{H}$, $\left.\mathrm{ArH}_{\text {ortho }}\right), 5.41$ (br s, 2H, NH$), 2.50\left(\mathrm{~s}, 3 \mathrm{H}, \mathrm{CH}_{3}\right), 1.18$ [s, 9H, $\left.\mathrm{C}\left(\mathrm{CH}_{3}\right)_{3}\right] \mathrm{ppm} .{ }^{13} \mathrm{C} \mathrm{NMR}\left(\mathrm{CDCl}_{3}\right.$, $100 \mathrm{MHz}): \delta=166.5,160.2,158.8,153.5,135.9(\mathrm{C}), 129.5,128.7,128.2(\mathrm{CH}), 121.8,116.1$, 89.1, 82.4 (C), 27.6, 23.5 $\left(\mathrm{CH}_{3}\right)$ ppm. $\mathrm{EM}(\mathrm{IE}): \mathrm{m} / \mathrm{z}(\%)=309.2 / 310.2 \quad[\mathrm{M}]^{+}$; 253.2/254.1/252.1/255.1 [M-57] $]^{+} ;$236.2/ 235.1/ 237.1/238.1 [M-73] $]^{+}$. Anal. Calcd for $\mathrm{C}_{18} \mathrm{H}_{19} \mathrm{~N}_{3} \mathrm{O}_{2}$ : C, 69.88; H, 6.19; N, 13.58. Found: C, 69.75; H, 6.08; N, 13.43.

tert-Butyl 5-amino-4,6-dicyano-3-methylbiphenyl-2-carboxylate (19). $\mathrm{MeOH}(30 \mathrm{~mL})$, toluene $(30 \mathrm{~mL})$, tert-butyl acetoacetate $(6.63 \mathrm{~mL}, 40 \mathrm{mmol})$, benzaldehyde $(4.06 \mathrm{~mL}, 40 \mathrm{mmol})$, malononitrile $(2.52 \mathrm{~mL}, 40 \mathrm{mmol})$ and $\mathrm{AcONH}_{4}(3.24 \mathrm{~g}, 42 \mathrm{mmol})$ were mixed and heated under reflux for $24 \mathrm{~h}$. Solvents were then removed in vacuum and then toluene $(30 \mathrm{~mL})$ and water $(3$ $\mathrm{mL}$ ) were added to continue refluxing for additional $24 \mathrm{~h}$. The reaction was concentrated and the residue partially purified by re-precipitation in $\mathrm{CH}_{2} \mathrm{Cl}_{2}-\mathrm{CHCl}_{3}$-hexane. The observed brown oil was discarded and the resulting fraction was concentrated and purified by flash column chromatography (5\% hexane in $\mathrm{CH}_{2} \mathrm{Cl}_{2}$ ) to yield pure compound (570 $\mathrm{mg}, 4 \%$ ) as a colorless solid.

Mp 200-202 ${ }^{\circ} \mathrm{C}$. IR (KBr): 3461, 3352, 3248, 2976, 2226, 2218, 1725, 1645, 1563, 1371, 1307 , 1283, 1216, 1148, 843, 753, $701 \mathrm{~cm}^{-1} .{ }^{1} \mathrm{H} \mathrm{NMR}\left(\mathrm{CDCl}_{3}, 400 \mathrm{MHz}\right): \delta=7.52-7.38(\mathrm{~m}, 3 \mathrm{H}$, $\left.\mathrm{ArH}_{\text {meta }}, \mathrm{ArH}_{\text {para }}\right), 7.37-7.31$ (m, 2H, $\left.\mathrm{ArH}_{\text {ortho }}\right), 5.35$ (br s, 2H, NH 2$), 2.55\left(\mathrm{~s}, 3 \mathrm{H}, \mathrm{CH}_{3}\right), 1.15$ [s, 9H, $\left.\mathrm{C}\left(\mathrm{CH}_{3}\right)_{3}\right] \mathrm{ppm} .{ }^{13} \mathrm{C} \mathrm{NMR}\left(\mathrm{CDCl}_{3}, 100 \mathrm{MHz}\right): \delta=165.7,151.8,148.3,145.3,136.3$ (C), 129.5, 128.6, $128.6(\mathrm{CH}), 127.0,115.1,115.1,97.5,96.0,82.8(\mathrm{C}), 27.6,19.4\left(\mathrm{CH}_{3}\right) \mathrm{ppm}$. $\mathrm{EM}(\mathrm{ES}): \mathrm{m} / \mathrm{z}(\%)=356.3 / 357.2 / 358.3[\mathrm{M}+23]^{+} ; 334.2 / 335.2[\mathrm{M}+1]^{+} ; 278.2 / 279.3 / 280.2[\mathrm{M}-$ $57+2]^{+} ; 260.2 / 261.2 / 262.0$ [M-73] . Anal. Calcd for $\mathrm{C}_{20} \mathrm{H}_{19} \mathrm{~N}_{3} \mathrm{O}_{2}$ : C, 72.05; H, 5.74; N, 12.60 . Found: C, 71.87; H, 5.91; N, 12.85 .

tert-Butyl 6-amino-5-cyano-2-methyl-4-phenyl-4H-pyran-3-carboxylate $(20) .{ }^{15}$ A solution of benzaldehyde $(4.06 \mathrm{~mL}, 40 \mathrm{mmol})$ in dry toluene $(100 \mathrm{~mL})$ under argon was treated with malononitrile $(2.52 \mathrm{~mL}, 40 \mathrm{mmol})$ and then piperidine $(0.40 \mathrm{~mL}, 4 \mathrm{mmol})$ was slowly added. The solution became gradually cloudy while a brownish oil appeared. After $12 \mathrm{~h}$ of stirring at $\mathrm{rt}$, tert-butyl acetoacetate $(6.63 \mathrm{~mL}, 40 \mathrm{mmol})$ and further piperidine $(0.1 \mathrm{~mL}, 1 \mathrm{mmol})$ were added. After $6 \mathrm{~h}$, the precipitate was collected by filtration, washed with cold toluene $(6 \times 20 \mathrm{~mL})$ and dried under vacuum, to yield the titled compound $(9.68 \mathrm{~g}, 78 \%)$ as a light pink solid.

${ }^{1} \mathrm{H} \mathrm{NMR}\left(\mathrm{CDCl}_{3}, 300 \mathrm{MHz}\right): \delta=7.34-7.26$ (m, 2H, ArH), 7.25-7.16 (m, 3H, ArH), 4.46 (br s, $\left.2 \mathrm{H}, \mathrm{NH}_{2}\right), 4.38$ (s, 1H, CHPh), 2.34 (s, 3H, $\left.\mathrm{CH}_{3}\right), 1.24$ [s, 9H, $\left.\mathrm{C}\left(\mathrm{CH}_{3}\right)_{3}\right] \mathrm{ppm}$. 
2-Amino-6-methyl-4-phenylnicotinonitrile (21). ${ }^{5} \mathrm{AcONH}_{4}(19.3 \mathrm{~g}, 250 \mathrm{mmol})$ was dissolved in $\mathrm{AcOH}(315 \mathrm{~mL})$ while heating. Compound 20 (7.8 g, $25 \mathrm{mmol})$ was then added and the mixture refluxed for $16 \mathrm{~h}$. Solvent was partially removed in vacuum and the resulting oil was treated with sat. $\mathrm{NaHCO}_{3}(1000 \mathrm{~mL})$ to $\mathrm{pH}=6-7$. A yellowish solid precipitated and was collected by filtration, washed with water $(6 \times 100 \mathrm{~mL})$ and re-dissolved in ethyl acetate $(50 \mathrm{~mL})$. The aqueous layer was treated with $\mathrm{HCl} 1 \mathrm{~N}$ to $\mathrm{pH}=2-3$ and extracted with ethyl acetate to confirm that no compounds were recovered from the aqueous layer. The re-dissolved precipitate was washed with water $(2 \times 20 \mathrm{~mL})$ and sat. $\mathrm{NaCl}(2 \times 20 \mathrm{~mL})$, dried $\left(\mathrm{MgSO}_{4}\right)$ and concentrated. The resulting crude was purified by re-precipitation in $\mathrm{CHCl}_{3}$-hexane (50:5). Yellowish solid (345 mg, $6.6 \%)$.

${ }^{1} \mathrm{H}$ NMR (DMSO- $\left.d_{6}, 300 \mathrm{MHz}\right): \delta=7.60-7.40(\mathrm{~m}, 5 \mathrm{H}, \mathrm{Ph}), 6.82$ (br s, 2H, NH$\left.{ }_{2}\right), 6.56(\mathrm{~s}, 1 \mathrm{H}$, $\left.\mathrm{CHCCH}_{3}\right), 2.32\left(\mathrm{~s}, 3 \mathrm{H}, \mathrm{CH}_{3}\right) \mathrm{ppm}$.

\section{Acknowledgements}

JMC thanks MICINN (SAF2006-08764-C02-01), Comunidad de Madrid (S/SAL-0275-2006), and Instituto de Salud Carlos III [Retic RENEVAS (RD06/0026/1002)] for support.

\section{References and Notes}

1. Samadi, A.; Marco-Contelles, J.; Soriano, E.; Álvarez-Pérez, M.; Chioua, M.; Romero, A.; González-Lafuente, L.; Gandía, L.; Roda, J. M.; G. López, M.; Villarroya, M.; García, A. G.; de los Ríos, C. Bioorg. Med. Chem. 2010, 18, 5861.

2. Goldfarb, D. S. U.S. Pat. Appl. Publ.163 545, 2009.

3. Gangjee, A.; Zeng, Y.; McGuire, J. J.; Kisliuk, R. L. J. Med. Chem. 2002, 45, 5173.

4. Benderitter, P.; Xavier de Araujo Junior; J.; Schmitt, M.; Bourguignon, J.-J. Tetrahedron 2007, 63, 12465.

5. (a) Kambe, S.; Saito, K.; Sakurai, A.; Midorikawa, H. Synthesis 1980, 366. (b) Mantri, M.; de Graaf, O.; van Veldhoven, J.; Göblyös, A.; von F. D. Künzel, J. K.; Mulder-Krieger, T.; Link, R.; de Vries, H.; Beukers, M. W.; Brussee, J.; Jzerman, A. P. J. Med. Chem. 2008, 51, 4449.

6. Papin, C.; Doisneau, G.; Beau, J.-M. Chem.-Eur J. 2009, 15, 53.

7. Vitnik, V. D. Synthetic Comm. 2009, 39, 1457.

8. TLC analysis showed many spots along the TLC plate, most part of which did not give rise to defined compounds after isolation.

9. This procedure has been used in our group to prepare pyrane derivatives that can be transformed into pyridines under reflux in the presence of $\mathrm{AcONH}_{4} / \mathrm{AcOH}$ : Marco, J. L.; de 
los Ríos, C.; Carreiras, M. C.; Baños, J. E.; Badía, A.; Vivas, N. M. Bioorg. Med. Chem. 2001, 9, 727.

10. This mechanism is in accordance with the one proposed by $\mathrm{Tu}$ in a related type of reaction. See: Tu, S.; Jiang, B.; Zhang, Y.; Jia, R.; Zhang, J.; Yao, C.; Shi, F. Org. Biomol. Chem. 2007, 5, 355.

11. In general, we have observed some degree of decomposition when using the described method, especially in its one-pot version. This degree of decomposition accounts for the observed low yields. Decomposition was critical in this example and the yield of compound 15 could not be increased.

12. This analysis has been carried out by Mr. César Pastor, SIDI, Facultad de Ciencias, UAM, Madrid, Spain. Single-crystal data and CIF file of compound 15 (CCDC 763716) have been deposited at the Cambridge Crystallographic Data Centre and can be obtained free of charge via www.ccdc.cam.ac.uk/conts/retrieving.html (or from the Cambridge Crystallographic Data Center, 12 Union Road, Cambridge CB21EZ, UK; fax: (+44) 1123-336-033; or email: deposit@ccdc.ac.uk).

13. Verniest, G.; Padwa, A. Org. Lett. 2008, 10, 4379.

14. Kuthan, J. Adv. Heterocyclic Chem. 1995, 62, 20. Ethyl acetoacetate has been previously used in our group to produce substituted pyridines. See ref. 9.

15. Srivastava, S.; Batra, S.; Bhaduri, A. P. Indian J. Chem, Sect. B 1996, 35B, 602. 